\title{
Pyrrhotite deposition through thermal projection to simulate iron sulphide slagging in oxyfuel combustion.
}

\author{
M.C. Mayoral*, J.M. Andrés, M.T. Izquierdo, B. Rubio
}

Instituto de Carboquímica, CSIC, Zaragoza (Spain)

*Corresponding autor. Address: Instituto de Carboquímica, CSIC. Miguel Luesma n.4, 50018 Zaragoza (Spain). E-mail: mayoral@icb.csic.es

\begin{abstract}
$\underline{\text { Abstract }}$
Oxyfuel combustion is envisaged as one of the main options for power production from fossil fuels in a carbon constrained scenery. There are still certain aspects of oxycombustion still on research stage, one of those is the issue of boiler materials resistance to corrosion due to solid deposits formed as a consequence of slagging in $\mathrm{CO}_{2}$ rich flue gases. The novel approach to the issue is the simulation of realistic slagging by pyrite projection through an oxyacetylene spray gun, flying along a controlled flame and impacting onto metallic surfaces of selected composition for fireside waterwall construction (F22, P91, 409, 347, 304H and I800HT). Metallic surface temperature was kept at $400,500,600$ and $700^{\circ} \mathrm{C}$, and after deposition, metallic coupons were aged for long periods (150 and 1500 hours) at the selected conditions $\left(\mathrm{O}_{2} / \mathrm{N}_{2}, \mathrm{CO}_{2} / \mathrm{N}_{2}\right)$. The characterization of deposits was performed with XRD, SEMEDX and carburization tests.
\end{abstract}

The first finding is that the oxidation scale progression is different when partially transformed pyrite covers metallic surfaces: chromium oxide grows as a response to oxidation between the steel and the deposit, less dense and partially interrupted, and no iron oxide scale is generated. There is a clear presence of chromium sulphides in competence with the chromium oxide. On the other hand, comparison of scales in $\mathrm{CO}_{2}$ vs. air indicates same chemical composition but different morphology: in air combustion, corrosion layers are thicker and cracked. These results can improve the prediction of operational problems in coal oxyfuel combustion. 


\section{Introduction}

Oxy-fuel coal combustion is envisaged as a promising technology for power production from fuel sources. There is an important public and private effort in the development of demonstration plants and calculations of final economic feasibility of carbon emissions reduction after oxyfuel combustion. Despite of that, ash related problems are still a matter of concern, recognized as a mayor source of uncertainty in the technology [1]. In fact, slagging, fouling, corrosion and fuel blending continue to be the leading coal quality concerns of utility personnel in commercial plants [2]. Among all the mineral constituents of coal, pyrite is considered as the main responsible of slagging on heat transfer fireside surfaces, involving operational problems and materials wastage. The background of the problem is well-known: pyrite plays a mayor role in slagging due to the formation of low melting $\mathrm{FeS}-\mathrm{FeO}$ intermediates (eutectic point at $940^{\circ} \mathrm{C}$ ) and the fluxing effect of $\mathrm{FeO}$ in aluminosilicates $[3,4]$. Early studies of pyrrhotite from coal pyrite $[5,6]$ gave a multiphase thermochemistry model still in use, whereas kinetic knowledge is less satisfactory [7]. For this reason, studies about iron transformations in coal combustion combining drop tube reactors for realistic conditions and instrumental techniques for characterization can be found in recent literature [8-10]. The interest of pyrite transformation is renewed for the case of $\mathrm{CO}_{2}$ recirculation in oxyfuel combustion $[11,12]$. In the present work, pyrite evolution is studied in simultaneous differential scanning calorimetry-thermogravimetry (DSC-TGA), which has been found to be very useful in describing deposition and fluxing phenomena in slagging conditions [13]. These results are compared with more realistic deposits: the new approach in this work is the use of a flame spraying gun, where pyrite particles flow inside a controlled flame at fast heating times reaching high flying speeds. In this way deposits are obtained at controlled surface temperatures and chemical composition is characterized by $\mathrm{XRD}$ and SEM as a function of gas temperature and composition, from air to 
complete $\mathrm{CO}_{2}$ recirculation as in oxyfuel combustion. On the other hand, the system ensures a high degree of contact between deposit and metallic surface. The chemistry of that interface can be studied in terms of oxyfuel gas composition. Examples of experimental evaluation of the fireside corrosion resistance can be found in the literature for oxycombustion $[14,15]$, although the present work is the first one focused in iron sulphide deposits impact in waterwall corrosion.

\section{Experimental}

Natural pyrite from coal rejects is sieved and $100>\varnothing>30$ is stored under inert atmosphere. Metallic materials were selected as a function to chromium content (purchased from Metal Samples Company Inc.) with complete composition shown in Table 1.

The thermobalance TA Inst. Q600 allows simultaneous thermogravimetry and calorimetry. Samples were laid onto the tared Pt pans and heat treatments consisted of a heating ramps of $50^{\circ} \mathrm{C} \cdot \mathrm{min}^{-1}$ to the desired temperature. A constant flow of $100 \mathrm{ml} \cdot \mathrm{min}^{-1}$ is maintained for all the purge gas studied: $\mathrm{N}_{2}, \mathrm{CO}_{2}$, and their mixtures.

The phase constitution of the iron species was investigated with XRD analysis using a Siemens D500 diffractometer set to select $\mathrm{Cu} \mathrm{K \alpha}$ radiation. The diffraction angle scanned was $20-70^{\circ} 2 \theta$ using a step size of $0.05^{\circ} 2 \theta$.

Sulphur content in samples was determined in a Carlo-Erba-1108 elemental analyzer.

For solids projection, a 5PII Sulzer Metco gun was selected, operated with hydrogen as fuel. The system comprised two Witt MM-Flex gas mixers provided of a proportional mixing valve with a control knob and percent scale, and variable flow settings. Stable flames were obtained with air or $\mathrm{O}_{2} / \mathrm{CO}_{2}-\mathrm{N}_{2}$ mixtures, so the adiabatic flame temperature and flow gas composition were easily controlled. Several theoretical initial 
gas compositions were given to an specific software (Gaseq) giving the adiabatic flame temperature and final flue gas composition. Once the conditions chosen, flames were ignited and real temperature was measured with a type $S$ thermocouple along flame previous to solid projection. On the other hand, velocity of particles could be monitorised by the Accuraspray system. The Accuraspray is a in-flight particle sensor that provides information on the average in-flight velocity of particles projected through the flames [16].

Metallic coupons are displayed along flame central line at several distances, depending of selected coupon temperature, ranging from 400 to $700^{\circ} \mathrm{C}$. Temperature is measured by a type $\mathrm{K}$ contact thermocouple in the reverse of the coupon. Once the selected $\mathrm{T}$ is reached, the gun is triggered and pyrite powder flows along flame and impacts. Projection is maintained for two minutes to obtain a desired depth of deposit. Surface composition was analyzed for each sample by X-ray diffraction.

After analysis, samples were treated in a furnace for $150 \mathrm{~h}$ and $1500 \mathrm{~h}$ periods in a constant flow of $50 \mathrm{ml} \cdot \mathrm{min}^{-1} \mathrm{O}_{2} / \mathrm{N}_{2}$ and $\mathrm{CO}_{2} / \mathrm{N}_{2}$, at 500 and $600^{\circ} \mathrm{C}$. Bare metallic coupons were aged as well at the same conditions to study both oxide development and carburization risk, and as blank experiments to establish comparison with projected metallic coupons. The composition of polished cross-section of samples was studied by means of scanning electron microscopy in a Hitachi S-3400 N microscope equipped with a $\mathrm{Si}(\mathrm{Li}) \mathrm{EDX}$ detector Röntec XFlash. 


\section{Results}

\subsection{Thermogravimetry}

The decomposition of pyrite with temperature is seen by DSC in the weight change and the endothermic peak. It is shown in Figure 1 for purge gas $\mathrm{CO}_{2}, \mathrm{~N}_{2}$ and a mixture $50 \%$ of both.

The endothermic decomposition of pyrite to pyrrhotite occurs between 500 and $700^{\circ} \mathrm{C}$ in the same extent and temperature for both purge gases, as follows:

$\mathrm{FeS}_{2} \rightarrow \mathrm{Fe}_{1-\mathrm{x}} \mathrm{S}+1 / 2 \mathrm{~S}_{2}$

As temperature increases, the melting point of each sample is reached. Pyrrhotite melts at $1080^{\circ} \mathrm{C}$ in $\mathrm{N}_{2}$ whereas the first endothermic peak onset temperature is $980^{\circ} \mathrm{C}$ when $\mathrm{CO}_{2}$ is the purge gas. New thermobalance experiments were performed, stopping the heating ramp just before the melting endothermic peaks, $1050^{\circ} \mathrm{C}$ for $\mathrm{N}_{2}$ as purge gas and $950^{\circ} \mathrm{C}$ for $\mathrm{CO}_{2}$ as purge gas. The samples obtained for both purge gas just after pyrite decomposition $\left(750^{\circ} \mathrm{C}\right)$ were as well obtained for analysis. Final composition of samples was determined by XRD (Figures $2 \mathrm{a}, 2 \mathrm{~b}$ and $2 \mathrm{c}$ ): pyrrhotite is the only specie in residue from pyrite heating in $\mathrm{N}_{2}$, whereas the residue when heated in $\mathrm{CO}_{2}$ denotes the presence of magnetite. It was proposed that $\mathrm{CO}_{2}$ dissociates in $\mathrm{CO}$ and $\mathrm{O}_{2}$ after heating to $500^{\circ} \mathrm{C}$, so transformation in $\mathrm{CO}_{2}$ involved partial oxidation to magnetite, in accordance with Equation 2 [12]:

$\mathrm{FeS}_{2}+\mathrm{CO}_{2}(\mathrm{~g}) \rightarrow \mathrm{Fe}_{3} \mathrm{O}_{4}+\mathrm{Fe}_{2} \mathrm{O}_{3}+\mathrm{COS}(\mathrm{g})+\mathrm{SO}_{2}(\mathrm{~g})$

Although further oxidation of magnetite to hematite is described in the equation, no traces of $\mathrm{Fe}_{2} \mathrm{O}_{3}$ has been detected in the diffractograms.

A semi-quantitative analysis of the two main possible crystalline species (pyrrhotite and magnetite) was performed with the software package EVA 8.0 (Socabim Inc., Bruker AX Systems) by the Reference Intensity Ratios (RIR) method. Semi-quantitative 
analysis is displayed in Table 2. Compositions calculated in this way are compared with weight change in thermogravimetry, and there is a coincidence of those values with the theoretical sulphur loss-oxygen gain calculated after the semiquant XRD values.

On the other hand, weight percentage of sulphur was obtained by elemental analysis, and results are displayed as well in Table 2 . Provided that only pyrrhotite is detected by $\mathrm{XRD}$ in $\mathrm{N}_{2}$ samples, it can be assumed that sulphur percentage allows iron calculation and the determination of sulphide stoichiometry. These results indicate that after pyrite decomposition, the obtained pyrrhotite goes on loosing sulphur as the temperature increases, as expected. In fact, pyrrhotite in sample $\mathrm{N}_{2}-750^{\circ} \mathrm{C}$ fits better with JPC2 card $25-0411\left(\mathrm{Fe}_{0.9} \mathrm{~S}, \mathrm{Fe} / \mathrm{S}=0.95\right)$ and pyrrhotite in $\mathrm{N}_{2}-1050^{\circ} \mathrm{C}$ with card $75-0601\left(\mathrm{Fe}_{1.05} \mathrm{~S}_{0.95}\right.$, $\mathrm{Fe} / \mathrm{S}=1.105)$. This tendency of sulphur loss with temperature is not observed in the case of pyrite treated in $\mathrm{CO}_{2}$ : all the diffractograms in Figure 2b fit with JPC2 card 25-0411. The main inference from these results is that in presence of $\mathrm{CO}_{2}$, pyrite decomposes into pyrrhotite of low $\mathrm{Fe} / \mathrm{S}$ ratio and, as temperature increases, sulphur is released and iron atoms are combined with oxygen rendering an oxysulphide, which $\mathrm{Fe}_{3} \mathrm{O}_{4}$ content increases while pyrrhotite stoichiometry is maintained. This oxysulphide forms an eutectic of low melting point, clearly seen in heat flow lines in Figure 1. In the same Figure, the heat flow line of pyrite treated in a mixture of $\mathrm{N}_{2}$ and $\mathrm{CO}_{2}$ is shown. There is an initial endothermic peak at $950^{\circ} \mathrm{C}$ and a second one, with larger area, at $1075^{\circ}$, which would indicate the coexistence of an oxysulphide melt and a pyrrhotite phase with a composition similar to that obtained in pure nitrogen. In fact, XRD profiles of pyrrhotite (Figure 2c) are similar to those obtained in $\mathrm{N}_{2}$ (Figure 2a) in terms of intensity ratios. These results have implications when applied to coal combustion: if low-NOx configuration is used, rendering pyrite decomposition in reductive gas flow, final composition would be pyrrhotite, whereas if $\mathrm{CO}_{2}$ recirculation is installed, $\mathrm{CO}_{2}$ rich flue gas tends to partially oxidize the iron sulphide into oxysulphide, so a decrease in 
melting point should be expected in oxyfuel combustion. Prior to rising any conclusion from these results obtained by DSC-TGA, further studies about pyrite decomposition were undertaken resembling particle fast heating in a flame spray gun, which is described in next section.

\subsection{Projection of pyrite over metallic coupons}

Flame spraying is a typical procedure for solids projection over selected surfaces, to produce coatings and fillings of desired composition. The basis of the technique is that the solids that flow along the flame attain high temperature and melt, so they fly as fused particles that impact as splats forming a dense layer of the material. The temperature and speed reached depend on the gas mixture that feeds the gun. Among all the thermal projection systems, flame spraying is not the system of choice for heavy duty metallic or ceramic coatings, where plasma spraying of high velocity oxyfuel projection are selected, because oxygen content in plume is better controlled and higher velocities are attained, rendering better quality coatings. Nevertheless, flame spraying is more flexible in terms of feeding gas and type of solids, so for this work a 5PII Sulzer Metco gun was selected, designed to operate with acetylene or hydrogen. Oxyacetylenic flames gave very high adiabatic flame temperature, so hydrogen was selected as fuel. Table 3 gives a list of gas mixtures and adiabatic flame temperatures selected for this study. Conditions 1 and 2 were used to obtain deposits with high oxygen excess in flue gas. Conditions 3-4, and 5-6 were used to compare the different flame profiles and coupon temperature in $\mathrm{N}_{2}$ and $\mathrm{CO}_{2}$ for the same flame $\mathrm{T}$ in low oxygen excess and stoichiometric oxygen. An example of the degree of control of the system is shown in Figure 3, where profiles of flame $\mathrm{T}$, coupon $\mathrm{T}$ and particle velocity are displayed. Flame temperatures presented a similar trend for C4-C6 conditions, as designed. Metallic targets are displayed as well along the plume axis to measure the impact surface 
temperature, revealing different profiles as a function of gas composition. The control of gas flows renders particle velocities around $20 \mathrm{~m} / \mathrm{s}$, which is in the range of particle velocities found in radiant zones in coal combustion [17]. This parameter is important to ensure a proper simulation of particle deformation and adherence upon impact. The convenience of this technique for solids projection is shown in Figure 4a-d. Figures 4a, $4 \mathrm{~b}$ and $4 \mathrm{~d}$ show the pyrrhotite deposited onto the metallic surface, and Figure $4 \mathrm{c}$ shows the cross section image where depth and porosity can be seen. These images indicate the satisfactory simulation of deposits formation since a dense and well adhered fused layer is obtained. Moreover, the technique allows the control of metal temperatures, which is an important parameter in slagging simulation: Figure 4d shows the external image of a deposit held at $500^{\circ} \mathrm{C}$ where surface crystallised oxides are observed. Surface composition of deposits obtained by the conditions studied was analysed by XRD and phase percentages are calculated from the diffractograms, results displayed in Table 4. The first important result is that pyrrhotite is the main specie found at $400^{\circ} \mathrm{C}$ for all the conditions studied, which it is to say, at the longer distances from flame front and longer residence time. The gun is triggered for two minutes in each experiment, so it can be considered that pyrite decomposes into pyrrhotite in a flying time of $2 \mathrm{~ms}$, and is deposited onto a metallic surface at $400^{\circ} \mathrm{C}$. There, it is swept by a flame at a temperature given in the trends in Figure 3, which is not higher than $600^{\circ} \mathrm{C}$. When metallic coupons are held at $500^{\circ} \mathrm{C}$, pyrrhotite tends to oxidise to magnetite and hematite, in an extent which depends on the oxygen excess in product gas: oxygen excess in conditions $\mathrm{C} 3$ and $\mathrm{C} 4$ involves that half of the iron is present as oxides, mainly hematite. No significant differences can be found as a function of $\mathrm{CO}_{2}$ presence or absence in the gas flow, comparing C3 vs. C4 and C5 vs. C6. In the case of coupons maintained at $600^{\circ} \mathrm{C}$, higher extent of oxidation is reached, although differences in flame temperature could account for that final composition. 


\subsection{Long treatment of bare and projected metallic coupons}

Oxidation scales for all the materials were measured and depths were compared as a function of temperature and oxidation gas for furnace treatments at $500^{\circ} \mathrm{C}$ and $600^{\circ} \mathrm{C}$ for 150 hours in $\mathrm{O}_{2} / \mathrm{N}_{2}$ and $\mathrm{O}_{2} / \mathrm{CO}_{2}$. As expected, nickel alloys did not suffer oxidation corrosion at 500 and $600^{\circ} \mathrm{C}$ treatments, and austenitic steels suffer minor surface oxidation. Ferritic steels as 409, P91 and F22 developed oxidation scales, composed of a dual layer of chromium oxides on the steel and outer iron oxides scales, thicker chromium oxide scale in the case of $\mathrm{CO}_{2}$ oxidation. This behaviour had been previously described in oxidation studies in oxycombustion environments [18,19]. In the present work, these samples were used as blank experiments to be compared with projected samples oxidation, as it will be shown below. On the other hand, these bare oxidised samples were analysed under standard carburization characterization, because the risk of chromium carbide compromising protective oxidation should be determined. It is worth mentioning in this point that the analysis indicated no risk of carburization. Aging of steels previously projected with pyrite (transformed into monosulphide pyrrhotite along flame) at $500^{\circ} \mathrm{C}$ for $150 \mathrm{~h}$ developed different oxidation patterns (Figure 5): chromium oxide grows as a response to oxidation between the steel and the deposit, less dense and partially interrupted, and no iron scale is generated. There is a clear presence of chromium sulphides in competence with the chromium oxide. Similar results are obtained for steel 409 . At $600^{\circ} \mathrm{C}$, Figure 6 shows the comparison of corrosion when aged in $\mathrm{CO}_{2}$ versus air treatment: sulphidation points were detected in the same extent for both cases. Moreover, when the comparison is extended to $1500 \mathrm{~h}$ (figure 7), the images show that sulphidation corrosion progress in depth, with an homogeneous distribution of sulphur in the chromium oxide corrosion scale. For those deposits with hematite composition, such as those obtained at $700^{\circ} \mathrm{C}$ pyrite projection (Table 4), not 
sulphidation was found at $1500 \mathrm{~h} 600^{\circ} \mathrm{C}$ aging periods, as expected since there was no sulphur involved in the oxidation chemistry, and the SEM images indicated the absence of surface chromium oxide nor other oxidation corrosion in the interface between the deposit and the metallic surface (Figure 8). In fact, the hematite deposit seem to behave as a protective scale to oxidation when comparing the images obtained for the same treatment in bare coupons. Those metallic coupons with higher chromium content were not affected by sulphidation.

\section{Discussion}

There are two different approaches to pyrite and mineral matter transformations studies: slow heating ramps, as those found in TGA or TPD-MS [12, 20-22], that ensure chemical reaction control of kinetics, and fast heating as in drop tubes, closer to pulverized coal boilers $[4,5,8,9]$ which need to account for particle size to describe diffusional limitations. These works are extensively reviewed in [7], and have as common starting point the kinetic model for pyrite transformation in combustion environment proposed in the late 80's [23]. There, a complete decomposition of pyrite into molten pyrrhotite is described to be reached in $40 \mathrm{~ms}$ (at the conditions selected for the calculations) and $2000^{\circ} \mathrm{C}$ as possible particle maximum temperatures. In this work, thermogravimetric studies described in Section 3.1 could give the conclusion that pyrite decomposition in $\mathrm{CO}_{2}$ atmospheres would render particles with lower melting point, implying lower viscosity which would involve higher capture rate and increased slagging. Nevertheless, the study scope is widened to rate of particle heating characteristic of that in an actual burner [24] with the use of the projection gun with the proper fuel gas mix to reduce flame temperature. But the main goal of the installation is its capability to operate with air or $\mathrm{O}_{2} / \mathrm{CO}_{2}$ mixtures, to be used in oxicombustion comparative studies. The results described in Sections 3.2. indicate that surface 
composition of iron sulphide deposits is more influenced by metal temperatures than by gas composition or temperature, so no relevant differences are found when comparing oxyfuel pyritic deposits with conventional combustion ones.

On the other hand, this work basis is that highly contacted deposit layer obtained with the gun resembles more accurately real deposition than the ash replenishment methods found in the literature. The results shown in Section 3.3. indicate that the presence of iron sulphides on the tubes influences the formation of corrosive deposits by increasing the local sulphur activity in similar extent in conventional and in oxyfuel combustion. And, when the deposit is oxidized, the active fireside sulphidation corrosion mechanism is hindered, and an oxidation chromium oxide scale is not formed.

\section{Conclusions}

Thermogravimetric studies demonstrate that pyrite transforms into low melting point FeO-FeS in $\mathrm{CO}_{2}$ gas and impacts onto selected metallic surfaces forming a highly contacted deposit. High gas and surface temperatures increases the degree of iron oxidation, which would imply a decrease in the extent of slagging, in the same extent for both conventional and oxycombustion. Pyrrhotite deposits involve a risk of sulphidation for low alloyed steels, being surface temperature the main parameter to describe deposit composition and its risk of corrosion: high temperature decreases the risk of sulphidation. No relevant differences were found in oxycombustion compared to conventional combustion.

\section{Acknowledgements}

The research work reported in this paper was party carried with the financial support from the RFCS contract number RFCR-CT-2006-00010 and from the Spanish Ministry of Science and Technology-FEDER with contract PN-. 


\section{References}

1. Buhre BJP, Elliott LK, Sheng CD, Gupta RP, Wall TF. Oxy-fuel combustion technology for coal-fired power generation. Progr Energy Combust Sci 2005; 31:283-307.

2. Harding NS, O'Connor DC. Ash deposition impacts in the power industry. Fuel Proc Tech 2007;88:1082-1093

3. Groves SJ, Williamson J, Sanyal A. Decomposition of pyrite during pulverized coal combustion. Fuel 1987;66:461-466

4. McLennan AR, Bryant GW, Stanmore BR, Wall TF. Ash formation mechanism during pf combustion in reducing conditions. Energy Fuels 2000;14:150-159

5. Huffman GP, Huggins KH, Levasseur AA, Chow O, Srinivasachar S, Mehta AK. Investigation of the transformations of pyrite in a drop-tube furnace. Fuel 1989;68:485-490

6. Lambert JM, Simkovich G, Walker PL. Production of pyrrhotites by pyrite reduction. Fuel 1980;59:687-690

7. Hu G, Dam-Johansen K, Wedel S, Hansen JP. Decomposition and oxidation of pyrite. Progr Energy Combust Sci 2006;32:295-314

8. Zeng T, Helble JJ, Bool LE, Sarofim AF. Iron transformations during combustion of Pittsburgh no. 8 coal. Fuel 2009;88:566-572

9. Korbee R, Shah KV, Cieplik MK, Bertrand CI, Vulthaluru HB, van de Kamp WL. First line ash transformations of coal and biomass fuels during pf combustion. Energy Fuels 2010;24:897-909

10. Gupta S, Al-Omari Y, Sahajwalla V, French D. Influence of carbon structure and mineral association of coals on their combustion characteristics for pulverized coal injection (PCI) application: Metallurgic Mater Tran B. 2006;37:457-473

11. Sheng C, Li Y. Experimental study of ash formation during pulverized coal combustion in $\mathrm{O}_{2} / \mathrm{CO}_{2}$ mixtures. Fuel 2008;87:1297-

12. Bhargava SK, Garg A, Subasinghe ND. In situ high-temperature phase transformation studies on pyrite. Fuel 2009;88:988-993

13. Mayoral MC, Izquierdo MT, Andrés JM, Rubio B. Mechanism of interaction of pyrite with hematite as simulation of slagging and fireside tube wastage in coal combustion. Thermochim Acta 2002;390:103-111

14. Środa S, Mäkipää M, Cha S, Spiegel M. The effect of ash deposition on corrosion behavior of boiler steels in simulated combustion atmospheres containing carbon dioxide (CORBI PROJECT). Materials and Corrosion 2006;57:176-181

15. 1st OXYFUEL COMBUSTION CONFERENCE, 8th -11th September 2009, Cottbus, Germany. Session 2c Material Related Issues Under Oxyfuel Combustion (5 papers).

16. Bisson JF, Lamontagne M, Moreau C, Pouliot L, Blain J, Nadeau F. Ensemble in-flight particle diagnostics under thermal spray conditions. Thermal Spray 2001, NEW SURFACES FOR A NEW MILLENNIUM : International Thermal 
Spray Conference (ITSC 2001), Date: MAY 28-30, 2001 SINGAPORE SINGAPORE 705-714, 2001

17. Bonin MP, Queiroz M. A parametric evaluation of particle-phase dynamics in an industrial pulverized-coal-fired boiler. Fuel 1996;75:195-205

18. Pirón Abellán J, Olszewski T, Penkalla HJ, Meier GH, Singheiser L, Quadakkers WJ. Scale formation mechanisms of martensitic steels in high $\mathrm{CO}_{2} / \mathrm{H}_{2} \mathrm{O}$-containing gases simulating oxyfuel environments. Materials at High Temperatures 2009;26:63-72

19. Huenert D, Schulz W, Kranzmann A. Corrosion of steels in H2O-CO2 atmospheres at temperatures between $500^{\circ} \mathrm{C}$ and $700^{\circ} \mathrm{C}$. ICPWS XV, Berlin, September 8-11 2008.

20. Tomeczek J, Palugniok H. Kinetics of mineral matter transformation during coal combustion. Fuel 2002;8:1251-1258

21. Yan J, Xu L, Ynag JJ. A study of the thermal decomposition of coal-derived pyrite. J Anal Appl Pyrolyisis 2008;82:229-234

22. Yani S, Zhang D. An experimental study into pyrite transformation during pyrolisis of Australian lignite samples. Fuel 2010;89:1700-1708

23. Srnivasachar S, Boni AA. A kinetic mofel for pyrite transformations in a combustion environment. Fuel 1989;68:829-836

24. ten Brink HM, Eenkhoorn S, Hamburg G. A fundamental investigation of the flame kinetics of coal pyrite. Fuel 1996;75: 945-951 


\begin{tabular}{l|l|l|l}
\hline \%wt & $\mathrm{Fe}$ & $\mathrm{Cr}$ & $\mathrm{Ni}$ \\
\hline F22 & 96.07 & 2.28 & \\
P91 & 88.86 & 8.78 & 0.12 \\
409 & 87.61 & 11.2 & 0.19 \\
347 & 69.6 & 17.45 & 9.43 \\
304H & 71.7 & 18.16 & 8.16 \\
I800HT & 45.69 & 19.88 & 31.29 \\
I617 & 1.03 & 21.93 & 54.66 \\
I690 & 8.98 & 28.8 & 61.2 \\
\hline
\end{tabular}

Table 1. Composition in weight percentage of the metallic materials selected.

\begin{tabular}{r|r|r|r|r|l}
\hline & & \multicolumn{2}{|c|}{ Iron specie (wt \%) } & & $\begin{array}{l}\text { Fe/S } \\
\text { Purge gas }\end{array}$ \\
\cline { 3 - 5 } & $\mathrm{T}^{\circ} \mathrm{C}$ & pyrrhotite & magnetite & S \% wt & ratio \\
\hline $\mathrm{N}_{2}$ & 750 & 100 & 0 & 37.95 & 0.936 \\
& 950 & 100 & 0 & 37.25 & 0.965 \\
& 1050 & 100 & 0 & 36.58 & 0.993 \\
& 1200 & 100 & 0 & 35.43 & 1.044 \\
\hline $\mathrm{CO}_{2}$ & 750 & 91 & 9 & 34.35 & \\
& 950 & 80 & 20 & 30.37 & \\
& 1200 & 69 & 31 & 24.60 & \\
\hline $\mathrm{N}_{2} \mathrm{CO}_{2}$ & 950 & 98 & 2 & 36.48 & \\
& 1070 & 95 & 5 & 34.11 & \\
& 1200 & 80 & 20 & 30.35 & \\
\hline
\end{tabular}

Table 2. XRD semiquantification and sulfur content as a function of temperature and purge gas 


\begin{tabular}{c|c|c|c|c|c|c}
\hline & Condition & $1(2)$ & 3 & 4 & 5 & 6 \\
\cline { 2 - 7 } & comburent & $\mathrm{O}_{2} / \mathrm{CO}_{2}$ & $\mathrm{O}_{2} / \mathrm{CO}_{2}$ & Air & $\mathrm{O}_{2} / \mathrm{CO}_{2}$ & Air \\
\cline { 2 - 7 } & oxygen & excess & excess & excess & Stoich. & Stoich. \\
\hline Initial & $\mathrm{N}_{2}$ & & & 0.57 & & 0.52 \\
composition & $\mathrm{O}_{2}$ & 0.30 & 0.20 & 0.15 & 0.17 & 0.14 \\
& $\mathrm{H}_{2}$ & 0.33 & 0.37 & 0.27 & 0.38 & 0.33 \\
& $\mathrm{CO}_{2}$ & 0.36 & 0.42 & & 0.43 & \\
\hline Adiab. Flame & & 2242 & 2301 & 2284 & 2249 & 2357 \\
T (K) & & & & 0.66 & & 0.61 \\
Final & $\mathrm{N}_{2}$ & & & 0.30 & 0.45 & 0.32 \\
& $\mathrm{H}_{2} \mathrm{O}$ & 0.39 & 0.43 & 0.47 & \\
& $\mathrm{CO}_{2}$ & 0.42 & 0.48 & & 0.47 & \\
& $\mathrm{CO}$ & 0.01 & 0.03 & & 0.05 & \\
& $\mathrm{O}_{2}$ & 0.16 & 0.03 & 0.02 & 0.005 & 0.00 \\
\hline
\end{tabular}

Table 3. Initial composition of the selected gas mixtures in flame spraying, and adiabatic flame temperatures and final composition calculated with Gaseq.

\begin{tabular}{r|l|c|c|c|c|c}
\hline $\begin{array}{r}\text { Coupon } \\
\mathrm{T}\end{array}$ & $\begin{array}{c}\mathrm{C} 2 \\
\mathrm{CO}_{2} \\
\left(\mathrm{O}_{2} 15 \%\right. \\
\text { excess })\end{array}$ & $\begin{array}{c}\mathrm{C} 3 \\
\mathrm{CO}_{2} \\
\left(\mathrm{O}_{2} 3 \%\right. \\
\text { excess }\end{array}$ & $\begin{array}{c}\mathrm{C} 4 \\
\mathrm{Air} \\
\left(\mathrm{O}_{2} 3 \%\right. \\
\text { excess })\end{array}$ & $\begin{array}{c}\mathrm{C} 5 \\
\mathrm{CO}_{2} \\
\left(\mathrm{O}_{2} \text { stoi. }\right)\end{array}$ & $\begin{array}{c}\mathrm{C} 6 \\
\text { Air } \\
\left(\mathrm{O}_{2} \text { stoi. }\right)\end{array}$ \\
\hline \multirow{2}{*}{$500^{\circ} \mathrm{C}$} & Pirrhotite & 67 & 87 & 81 & 84 & 88 \\
& Magnetite & 33 & 13 & 19 & 16 & 12 \\
\hline $500{ }^{\circ} \mathrm{C}$ & Pirrhotite & 25 & 11 & 17 & 28 & 79 \\
& Magnetite & 38 & 47 & 35 & - & - \\
& Hematite & & 825 & 875 & 650 & 850 \\
\cline { 2 - 7 } & Flame T $\left({ }^{\circ} \mathrm{C}\right)$ & 14 & 22 & 11 & 38 & 21 \\
$600^{\circ} \mathrm{C}$ & Pirrhotite & 14 & 13 & 20 & 11 & 14 \\
& Magnetite & 72 & 65 & 69 & 51 & 65 \\
\hline & Hematite & & 1210 & 1125 & 1000 & 1230 \\
\cline { 2 - 7 } & Flame T $\left({ }^{\circ} \mathrm{C}\right)$ & & & & 11.5 & - \\
\hline $700^{\circ} \mathrm{C}$ & Pirrhotite & & & & - & - \\
& Magnetite & & & & 88.5 & 100 \\
\hline & Hematite & & & & 1230 & 1400 \\
\cline { 2 - 7 } & Flame T $\left({ }^{\circ} \mathrm{C}\right)$ & & & & \\
\hline
\end{tabular}

Table 4. XRD composition of deposits as a function of coupon temperature, and measured flame temperature at each point. 


\section{Caption of Figures.}

Figure 1. Heat flow profiles in DSC of natural pyrite in $\mathrm{N}_{2}, \mathrm{CO}_{2}$ and a mixture $50 \% \mathrm{CO}_{2}-\mathrm{N}_{2}$ as purge gases.

Figure 2. XRD of pyrrhotite samples obtained at different temperatures for the three purge gas studied: (a) $\mathrm{N}_{2}$, (b) $\mathrm{CO}_{2}$ and (c) $50 \% \mathrm{CO}_{2}-\mathrm{N}_{2}$

Figure 3. Profiles of flame temperature, coupon temperature and particle velocity as a function of distance in flame axis for condition $\mathrm{C} 3$ and $\mathrm{C} 4$.

Figure 4. (a) Secondary image of deposit at $400^{\circ} \mathrm{C}$; (b) idem at x500 magnification; (c) back-scattered image of cross section of deposit at $600^{\circ} \mathrm{C}$; (d) idem surface.

Figure 5. Metallic coupon P91 aged for 150 hours, (a) aged at $500^{\circ} \mathrm{C}$, in $\mathrm{CO}_{2}$, (b) idem, previously projected, (c) detailed magnification of (a) and elemental mapping, (d) detailed magnification of (b) and elemental mapping.

Figure 6. Metallic coupon 409 aged for 150 hours, (a) aged at $600^{\circ} \mathrm{C}$ in $\mathrm{CO}_{2}$ and elemental mapping detailed magnification, (b) aged at $600^{\circ} \mathrm{C}$ in air and elemental mapping detailed magnification.

Figure 7. Metallic coupon 409 aged for 1500 hours at $600^{\circ} \mathrm{C}$ in $\mathrm{CO}_{2} / \mathrm{N}_{2}$ and elemental mapping detailed magnification.

Figure 8. Metallic coupons 409 and P91 aged for 1500 hours at $600^{\circ} \mathrm{C}$ in absence and in presence of deposit (projected at $700^{\circ} \mathrm{C}$ ). 


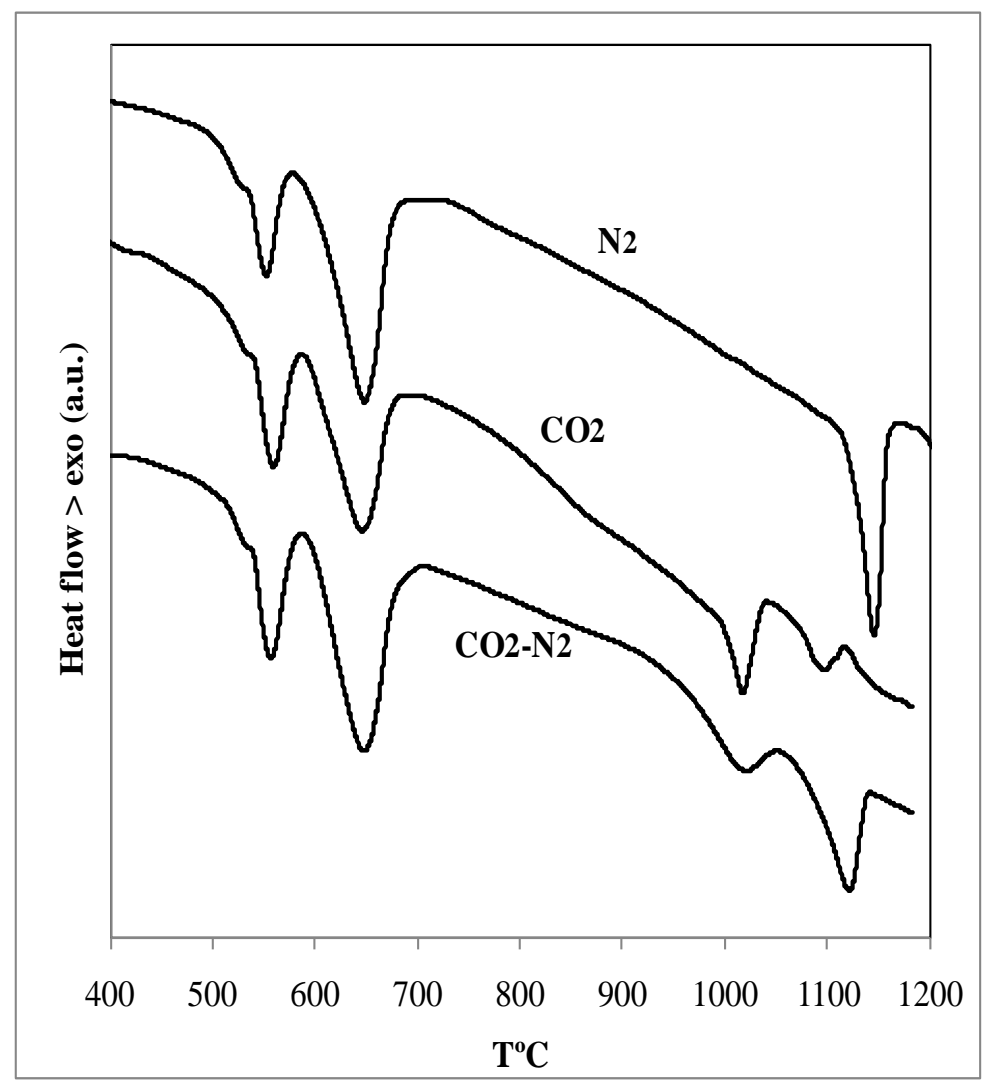

Figure 1.

Heat flow profiles in DSC of natural pyrite in $\mathrm{N}_{2}, \mathrm{CO}_{2}$ and a mixture $50 \% \mathrm{CO}_{2}-\mathrm{N}_{2}$ as purge gases. 

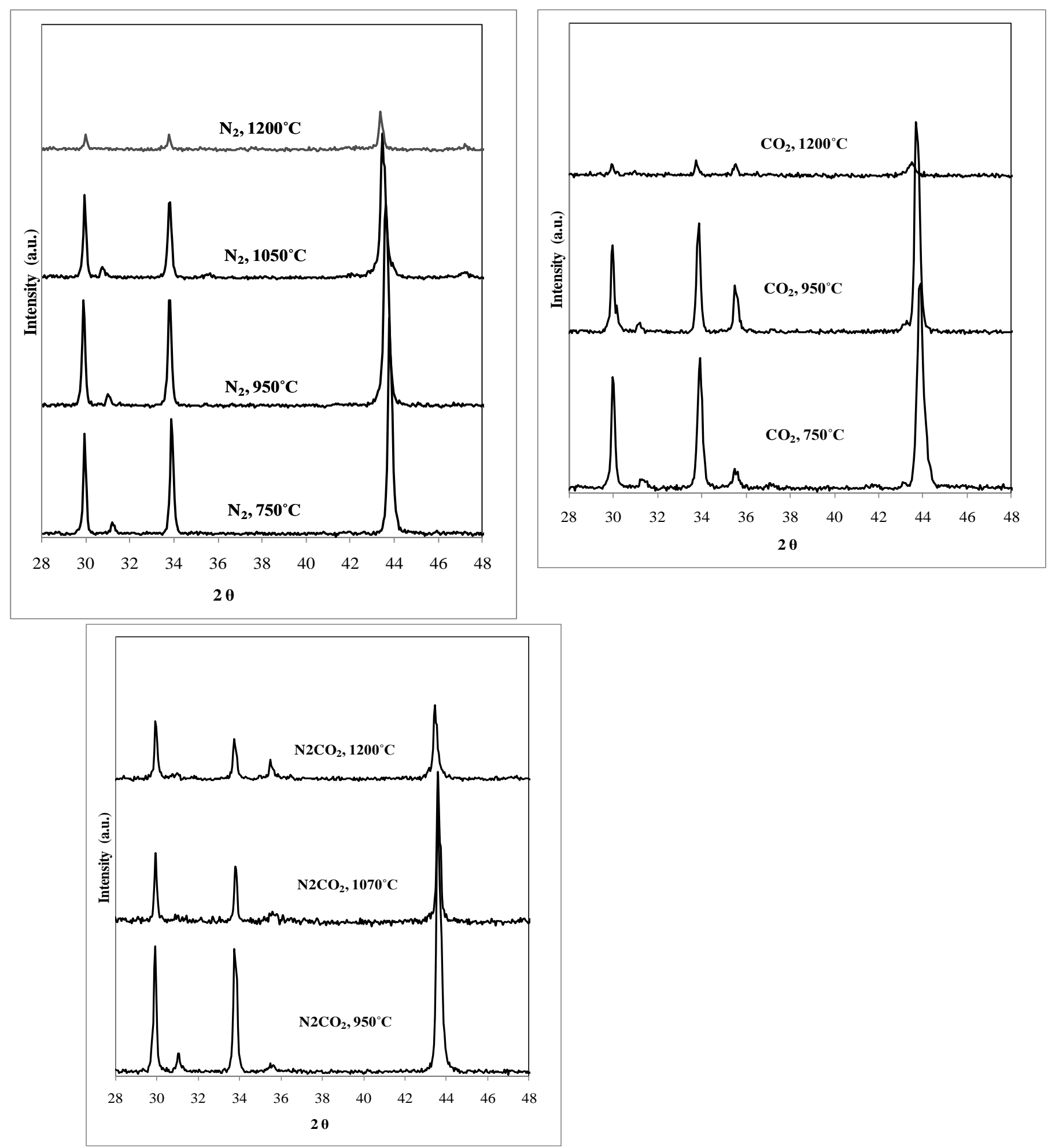

Figure $2 \mathrm{a}, 2 \mathrm{~b}$ and $2 \mathrm{c}$. 


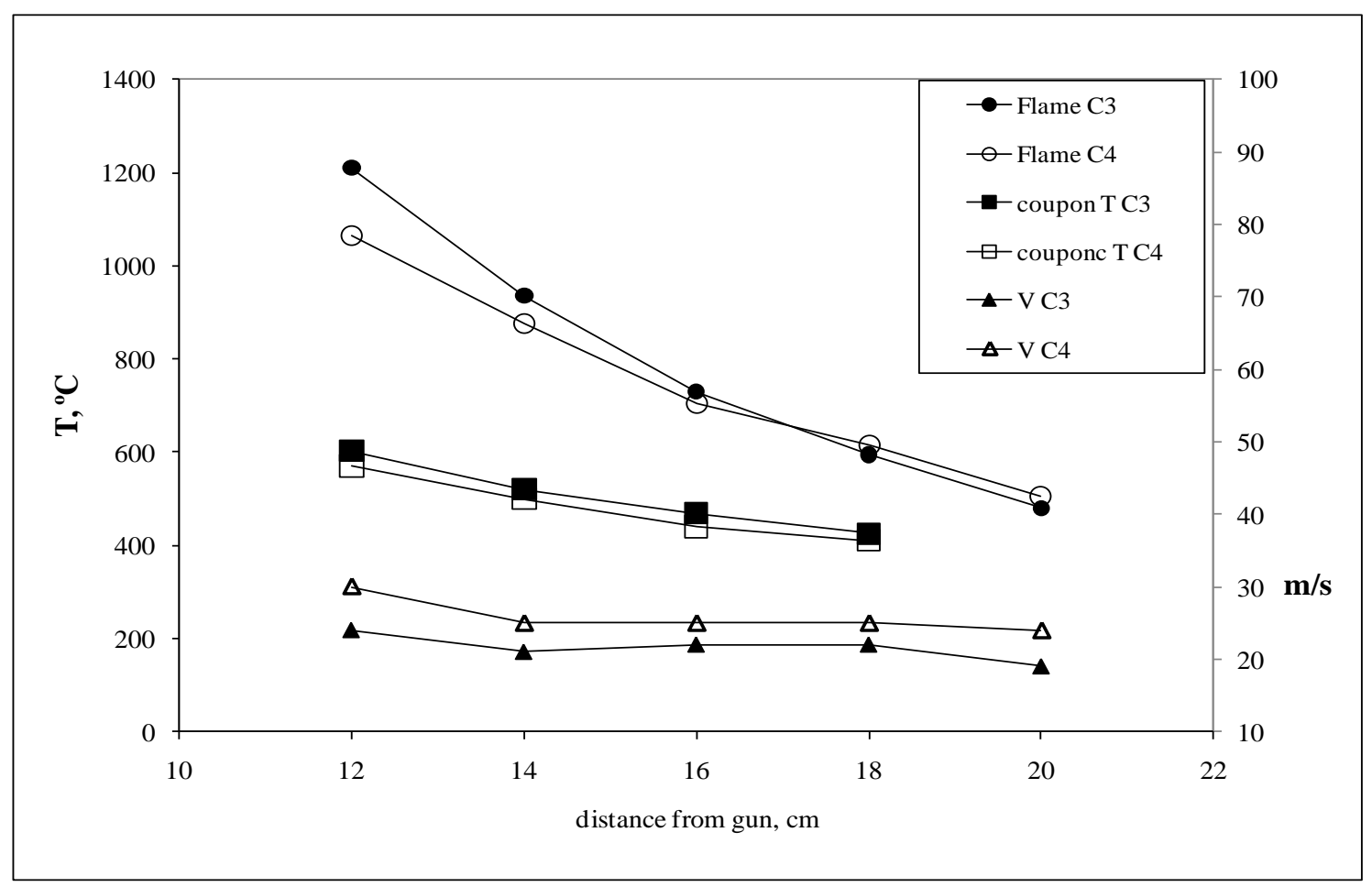

Figure 3

Profiles of flame temperature, coupon temperature and and particle velocity as a function of distance in flame axis for condition $\mathrm{C} 3$ and $\mathrm{C} 4$. 

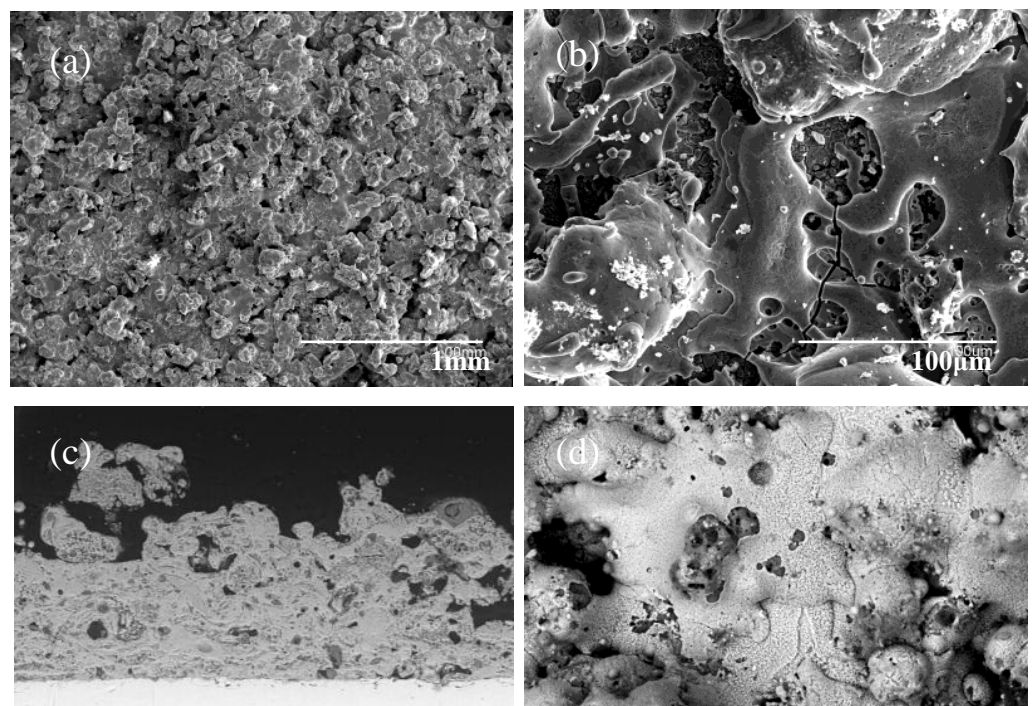

$100 \mu \mathrm{m}$

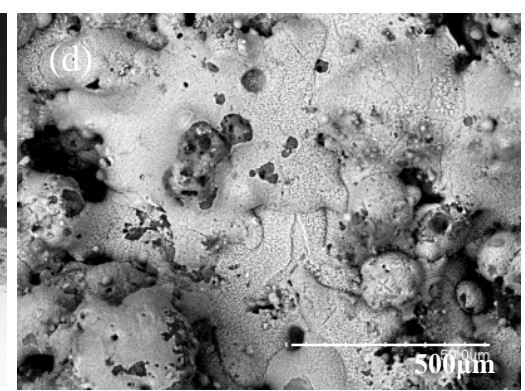

Figure 4. (a) secondary image of deposit at $400^{\circ} \mathrm{C}$; (b) idem at x500 magnification; (c) backscattered image of cross section of deposit at $600^{\circ} \mathrm{C}$; (d) idem surface. 


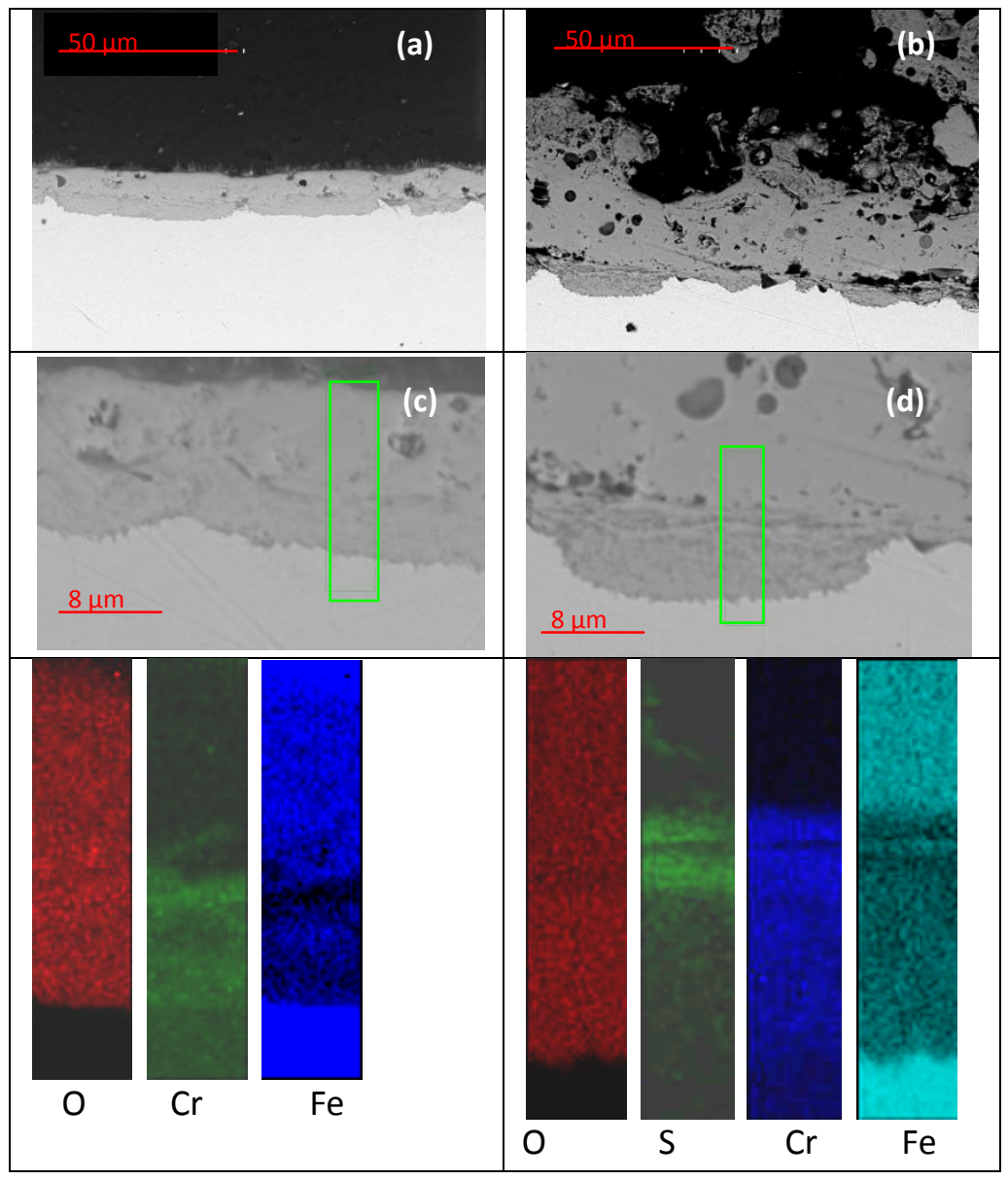

Figure 5. Metallic coupon $\mathrm{P} 91$ aged for 150 hours, (a) aged at $500^{\circ} \mathrm{C}$, in $\mathrm{CO}_{2}$, (b) idem, previously projected, (c) detailed magnification of (a) and elemental mapping, (d) detailed magnification of (b) and elemental mapping. 


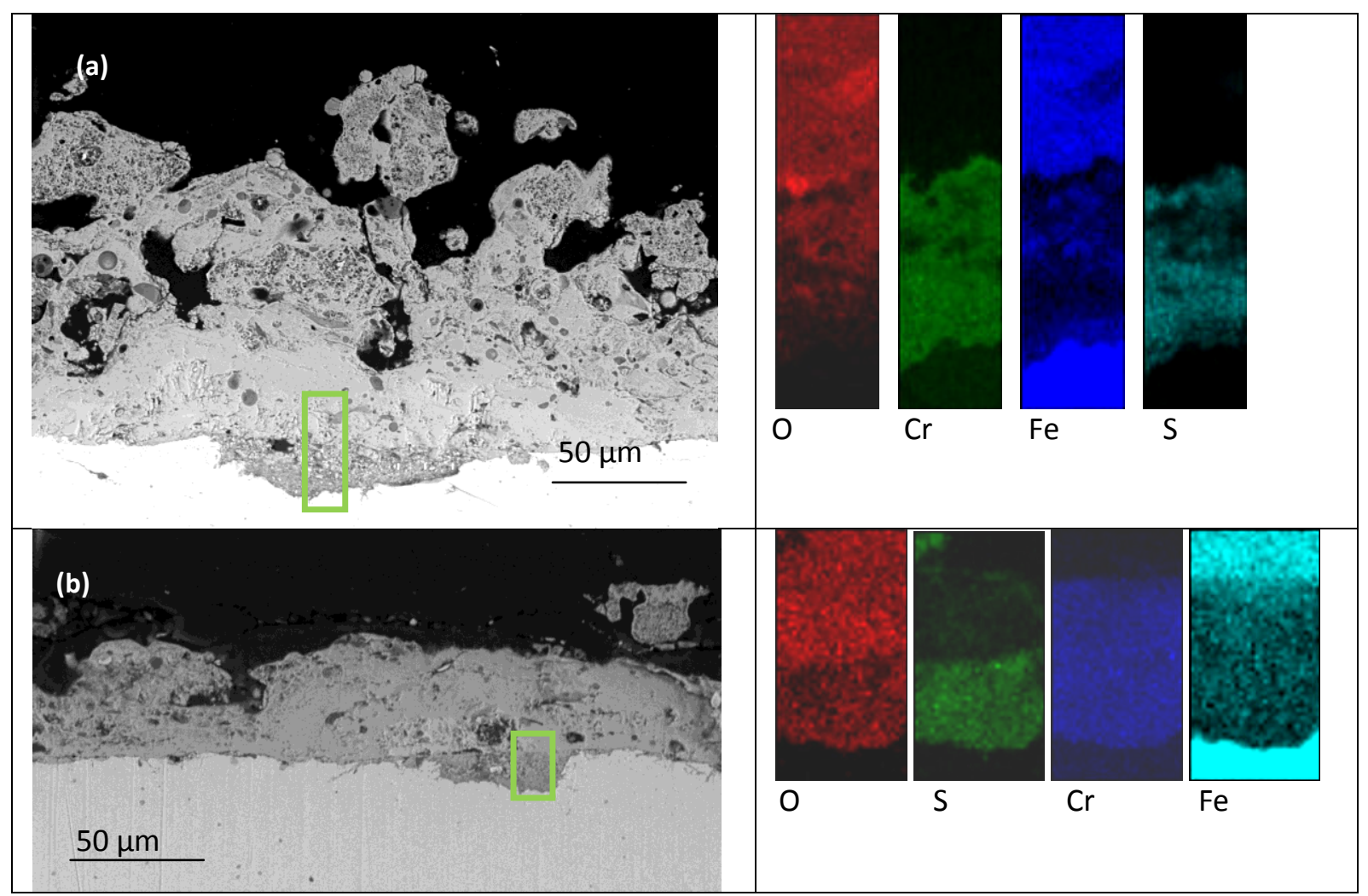

Figure 6. Metallic coupon 409 aged for 150 hours, (a) aged at $600^{\circ} \mathrm{C}$ in $\mathrm{CO}_{2}$ and elemental mapping detailed magnification, (b) aged at $600^{\circ} \mathrm{C}$ in air and elemental mapping detailed magnification. 


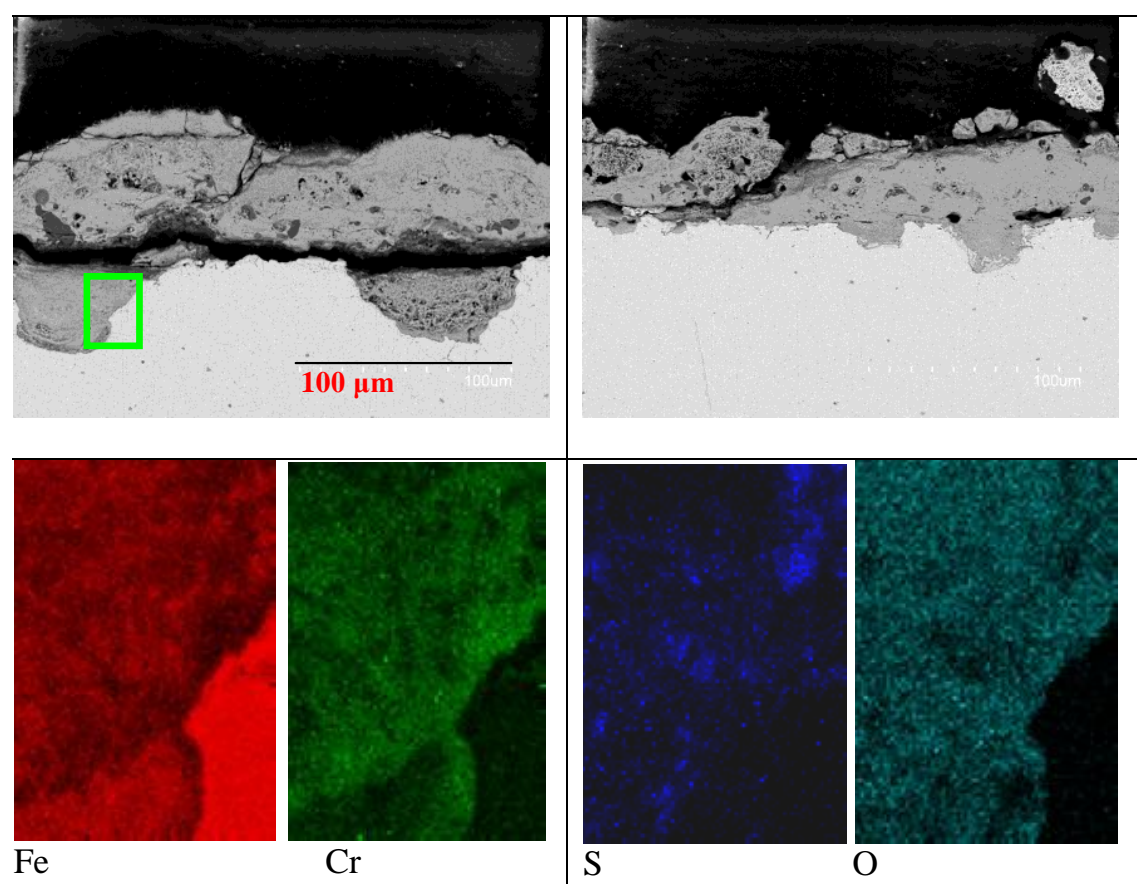

Figure 7. Metallic coupon 409 aged for 1500 hours at $600^{\circ} \mathrm{C}$ in $\mathrm{CO}_{2} / \mathrm{N}_{2}$ and elemental mapping detailed magnification. 

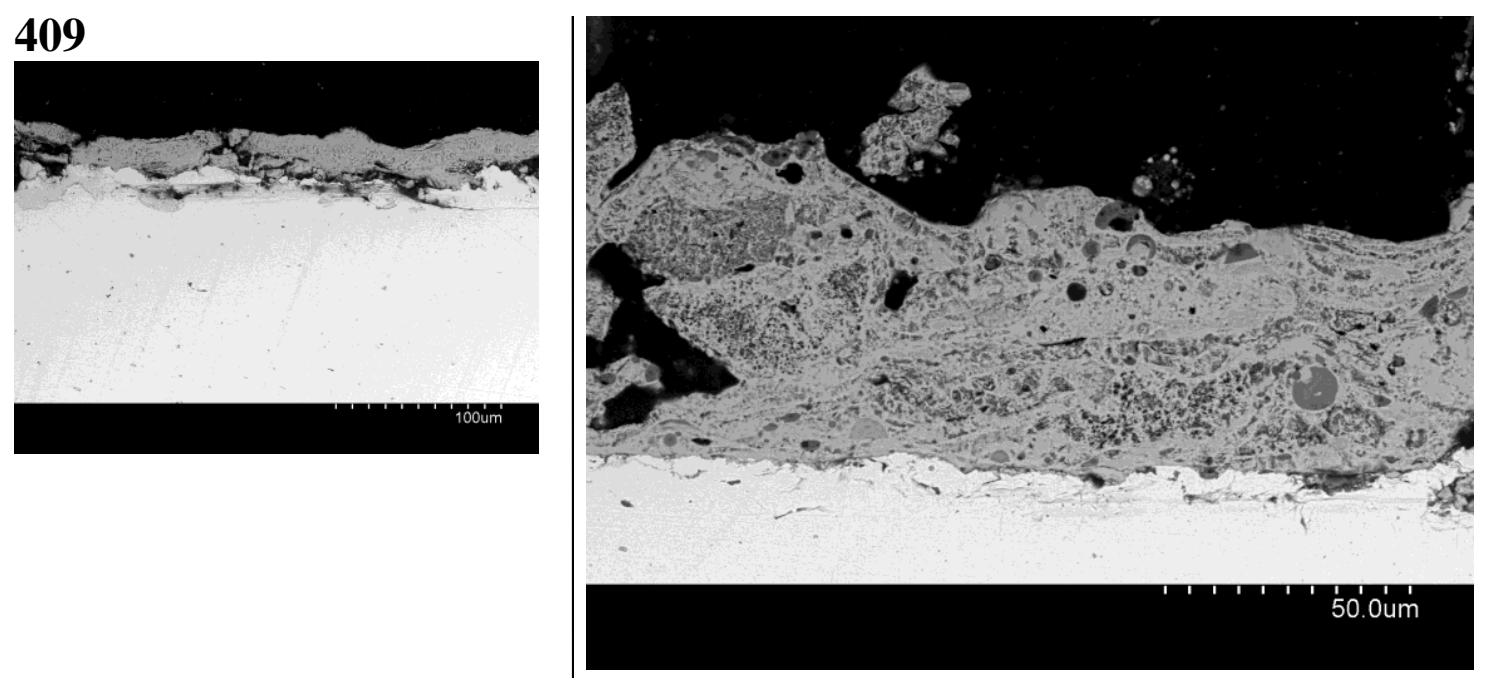

\section{P91}
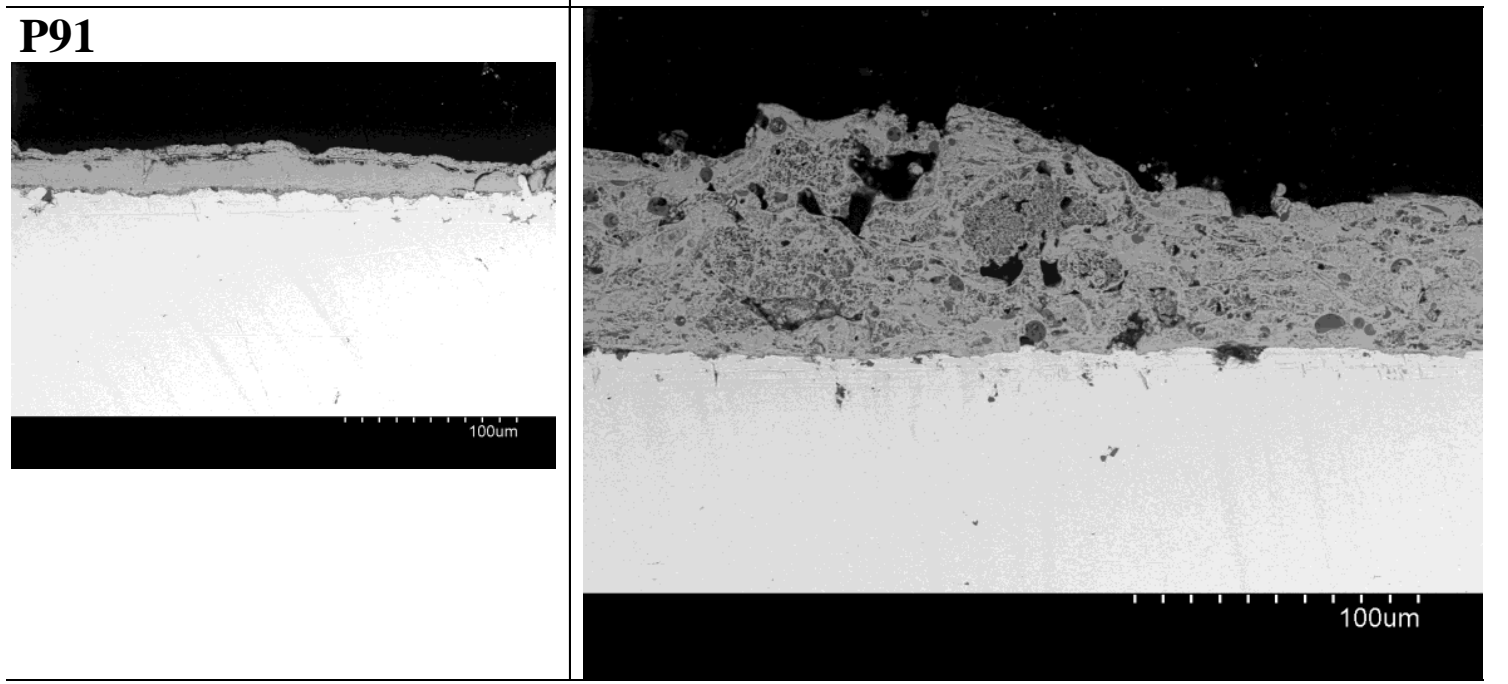

1 ' ' ' ' ' ' 100um

Figure 8. Metallic coupons 409 and P91 aged for 1500 hours at $600^{\circ} \mathrm{C}$ in absence and in presence of deposit (projected at $700^{\circ} \mathrm{C}$ ) 